\title{
Students' Subjective Responses toward Selected Poems in Introduction to Literature Class
}

\author{
Yan Ardian Subhan \\ ${ }^{1}$ English Department, Faculty of Letters, Universitas Pamulang \\ e-mail: ${ }^{1}$ dosen00184@unpam.ac.id

\begin{tabular}{ccc}
\hline Diterima & Direvisi & Disetujui \\
$27-07-2021$ & $28-08-2021$ & $15-09-2021$ \\
\hline
\end{tabular}

\begin{abstract}
Students' understanding in form of their responses to literature is important to be researched by educators and researchers. According to Marshall (2000), student response is an indicator of learning's success. Therefore, this paper discusses students' subjective responses to literature as result of learning Introduction to Literature subject in one of private universities in Banten, Indonesia. The goal of the research was intended to get insight about students' subjective responses, to understand their comprehension toward selected literary works. The data were taken from essay-test results of their participation in the class. This study is hopefully gaining more understanding of students' responses to literature.
\end{abstract}

Kata Kunci: subjective response, poetry analysis, descriptive study

\begin{abstract}
Abstrak - Pemahaman siswa dalam bentuk tanggapan mereka terhadap sastra penting untuk diteliti oleh para pendidik dan peneliti. Menurut Marshall (2000), respon siswa adalah indikator keberhasilan belajar. Oleh karena itu, makalah ini membahas tanggapan subyektif siswa terhadap sastra sebagai hasil pembelajaran mata pelajaran Pengantar Sastra di salah satu universitas swasta di Banten, Indonesia. Tujuan dari penelitian ini dimaksudkan untuk mendapatkan wawasan tentang tanggapan subjektif siswa, untuk memahami perspektif mereka terhadap karya sastra yang dipilih. Data diambil dari hasil tes esai partisipasi mereka di kelas. Studi ini mudah-mudahan mendapatkan lebih banyak pemahaman tentang respons siswa terhadap sastra.
\end{abstract}

Kata Kunci: respon subjektif, analisis puisi, kajian deskriptif

\section{INTRODUCTION}

Many people enjoy reading, listening, watching, not only informational work but also entertainments such as short storie, novel, poem, theater, film, song, etc. these belong to Literary works. Work of literature is created from the interaction process between people and thought, feelings, experiences, even environment, and communities. In other words, literary works are the reflection of the experiences, feelings, and ideas of life. Literary works also talk about love and hate, war and peace, happiness and sadness, etc. Many people are interested to inspect human life stories, with all behavior and consequences, that's why literary works are demanded to be used in many purposes including education purposes (Subhan, 2016).

Several studies have been conducted and concluded that literature is an important lesson to improve literacy skills and critical thinking, such as researches conducted by Purves, Rogers, and Soter (1990), Langer (1991), Cobine (1996), and Spiegel (1998). In addition, literary works are also able to teach noble values through reading the emotion and people aspiration from characterization (Rosenblatt,
1999), and also appreciate cultural values and artworks in general (Purves et.al., 1990).

What is "literature"? Terry Eagleton (1996) in his book entitled Literature Theory: A Comprehensive Introduction, says that literature is highly valued writing. Mostly literary works are always in the form of writing or text. If the text has received the title as a literary work, then the text must have certain meanings. Then, how can a text be meaningful?

In answering this question, according to Martin McQuillan (2019), a text will only be meaningful if the text is read, or when the reader interacts with the words on the page of the text in order to produce meaning. He called the reading activity as an active participation from readers to build meaning from a piece of writing. Reading, therefore, is something that the reader has a role in and is something that happens during a certain period of time. In McQuillan's terminology, reading only happens when the reader actually reads (actively participates in the construction of meaning) of a text that actually exists.

What is expressed by McQuillan above 
shows the importance of the role of the reader in the meaning of a literary work. For this reason, it is undeniable that the reader is actually the scorer of a literary work. The high and low value of a literary work is determined by how the response of the text's readers. Based on these things, a theoretical concept emerged about the response of readers, better known as Reader-response Theory.

In its journey, reader-response theory has experienced many developments. Various variations of this theory emerge with the perspective and focus of different studies. One theory that will be the focus of this discussion at the same time is Transactional Reader-response theory. Just like the general readerresponse theory, this theory also sees the reader as a very important object in the formation of meaning. Then, what is special about this theory? These questions will be answered in the discussion in the next section.

\section{History and Basic Concepts of Reader- response}

Contemporary reader-response theory is developed from philosophical hermeneutics and phenomenology in the 1950s. However, attention to the process of reading actually emerged during the 1930 s as a reaction to a growing tendency to reject the reader's role in the creation of meaning, which is a formal principle of New Criticism that dominated critical practice in the 1940s and 1950s. In New Criticism, the meaning of a literary work lies in the text itself and is independent of anything. The meaning is not the result of the author's intention and cannot be changed by the response of the reader. New Critics believe that the attention to the response of the reader will create confusion between what the text actually is and what is done by the text (what the text is with what the text does). Reader response theory argues that the meaning of a text cannot be separated from what is done (said) by the text. The theory, which did not receive much attention until the 1970s, believes at least two things: (1) that the role of the reader cannot be separated from our understanding of literary works, and (2) that the reader does not passively consume the meaning presented by a literary text objective; but rather actively creating meaning that they find in literary works (Tyson, 1996).

The belief that readers actively make meaning, as above, means that different readers can read the same text in different ways. In fact, readerresponse theorists believe that a reader who reads a text on two different occasions might produce different meanings. This is because of the many variables that contribute to our experience of the text, for example, the knowledge we gain from the first and second readings, personal experiences that appear on the sidelines of the two readings, change of mood (mood) at the time of the two reading recess, or change of destination in reading the text (Tyson, 1996).

\section{Reader-response Transactional Theory}

Transactional reader-response theory (transactional reader-response) is often associated with Louise Rosenblatt, because she contributed a lot of thoughts in the development of this theory. Transactional reader-response discusses transactions between texts and readers. Rosenblatt does not reject the importance of the text in supporting the reader, but he argues that both are needed in the creation of meaning (Tyson, 1996).

Then, how the transaction goes? As discussed above, the meaning of a text appears to the reader influenced by various variables. A text acts as a stimulus or stimulus in which we respond in our own way. Feelings, memories, and associations will appear when we read. All of these things affect us in understanding and interpreting a text. Literary works that we have read before, all of our knowledge, and even our physical condition and mood today also influence this understanding and meaning. When we read, the text can act as a blueprint that can be used to improve our interpretation when we realize that we have made an interpretation that goes too far with what is written in the text. The process of improving this interpretation usually results in our return to reread the previous section in order to consider some developments from the text we have found. Thus, a text guides us to make corrections independently of our interpretations in order to develop a complete interpretation. So the creation of a literary work is a product of the transaction between the reader and the text, both of which are equally important in the process (Tyson, 1996).

In her book, The Reader, The Text, The Poem, Rosenblatt introduces two reading strategies that can be used to identify the motives of the readers and their "transactions" with literary works. The first is aesthetic reading, in which the reader pays special attention to what happens during his reading (Davis and Womack, 2001). When we read in this aesthetic mode, we experience a personal connection with the text that makes our attention focus on the emotional subtlety of the language and encourages us to make judgments (Tyson, 1996). The second strategy is non-aesthetic reading where the reader focuses attention on the traces of knowledge and data that will remain after the reading process. Rosenblatt calls this strategy an efferent reading, in which readers make themselves interested in what will be obtained materially from the reading experience (Davis and Womack, 2001). When we read in efferent mode, we focus on the information contained in the text, as if the text is a repository of facts and ideas that we can carry 
everywhere. Therefore, in order to bring about transactions between the text and the reader, our reading approach or strategy to the text must be aesthetic rather than efferent. Without an aesthetic approach, there is no transaction between the reader and the text that can be analyzed (Tyson, 1996).

The followers of Wolfgang Iser (a literary expert from Germany) might explain what Rosenblatt calls the blueprint and stimulus function of the text with the terms of meaning that are always offered by every text: determinate meaning and indeterminate meaning. The meaning of determinate refers to what is called the fact of the text, certain events in the storyline, or the clear physical description provided by the words on a page. In contrast, the meaning of indeterminate refers to "gaps" ("gaps") in the text - for example actions that are not clearly explained or as if they have several explanations - that allow or even invite readers to create interpretations according to their own. Thus, Rosenblatt's efferent approach depends entirely on the determinate meaning, while the aesthetic approach depends both on the determinate meaning and the indeterminate meaning (Tyson, 1996).

The interaction between determinate meaning and indeterminate results in a number of experiences that are constantly on the reader: retrospect, or think back to what we have read before in the text; anticipation of what will happen next, fulfillment or disappointment over our anticipation; revisit of our understanding of a character or event; etc. At one point in a literary work, the meaning of determinate often appears, but at the next point, it could be that the meaning of indeterminate becomes more frequent. This happens in line with our point of view which turns into various perspectives presented by, for example, narrators, characters, and events from unraveling storylines. So, according to Iser, the text itself guides us through the various processes involved in interpreting the meaning of the text (Tyson, 1996).

According to transactional theorists, different readers emerge with different but acceptable interpretations. This happens because the text allows for the emergence of a variety of acceptable meanings, namely those that have textual support. However, due to the existence of real texts involved in this process which is the basis of our response, not all readings are acceptable, in fact, some readings can be more accepted than others (Tyson, 1996).

\section{Subjective Reader Response Theory}

It is very different from effective language styles and all forms of transactional reader responses theory, subjective reader-response theory does not call for analysis of textual cues. To subjective reader-response criticism, led by David Bleich's work, reader response is texts, both in the sense that there is no literary text outside the meaning created by reader interpretation and in the sense that the text analyzed by criticism is not literature work but written response from the reader.

To understand how there are no literary texts outside the meanings made by readers' interpretation, we need to understand how Bleich (1975) defines literary texts. Like many other reader-response criticisms, he distinguishes between what he calls real objects and symbolic objects. Real objects are physical objects, such as tables, chairs, cars, books, and the like. Literary text printed pages are real objects. But his experience made when someone reads the printed page, like the language itself, is a symbolic object because it happens not in the physical world but in the conceptual world, namely in the reader's mind. This is why Bleich calls reading - feelings, relationships, and memories that occur when we react subjectively to words printed on a page-symbolization: our perception and identification of our reading experience creates a conceptual world, or symbolic, in our minds when we read. Therefore, when we interpret the meaning of the text, we actually interpret the meaning of our own symbolization: we interpret the meaning of the conceptual experience we made in response to a text. $\mathrm{He}$ thus calls the act of re-interpretation of symbolization. Re- symbolization occurred when our experience of texts results in us a desire for explanation. Our evaluation of text quality is also an act of re-symbolization: we don't like or dislike text; we like or don't like our symbolism about it. Thus, the text we are talking about is not the actual text page: that is the text in our mind. Because the only text is the text in the reader's mind, this is the text analyzed by subjective reader-response criticism, for whom the text is equated with a written response reader. Bleich, whose main interest is pedagogical, offers us methods for teaching students how to use their responses to learn about literature or, more precisely, to learn about literary responses. Contrary to popular opinion, subjective criticism is not a matter anything is free for all. This is a coherent methodology and aims to help us students and ourselves produce knowledge about the reading experience.

In addition, responses can be characterized, for example, as pleasure, discomfort, attractiveness, disappointment, relief, or satisfaction, and may involve a number of emotions, such as fear, excitement, and anger. A student response analysis statement might reveal that certain responses produce, for example, from identification with certain characters, from fulfilling fierce desires, from eliminating (or adding to) feelings of guilt, or the like. The goal here is for students to understand their responses, not just report them or make excuses 
for them. So, a response-analysis statement is a thorough and detailed explanation of the relationship between certain textual elements, certain personal responses, and the meaning of the text have for students as a result of his personal meeting with it.

This research will limit only by looking at student responses in written form. Their subjective writing in the form of their sentences is expected to have certain "symbols" as a form of their understanding of the text. As according to Bleich's theory, students will re-formulate their understanding toward the selected literary works by process of "re-symbolization". By seeing these products, we may see their interpretation as their attempt towards understanding. Hopefully, their writing products will show their involvement of emotions as it is also important as it indicates that they understand their own responses.

\section{RESEARCH METHODOLOGY}

\section{Research Design}

This research dealt with qualitative approach in collecting, analyzing, and describing the data.

\section{Setting and Participants}

An English class, with 25 students at English Department, Universitas Pamulang with their ages varied between 18 and 24 are the participants for this study. These are all students of the third academic semester, majoring in English Literature and their performance on tests are further evaluated.

These participants came from class of Introduction to Literature course held once a week, through the exact same academic rituals intended for the course and taught by a same instructor. Students in the class are required to read some samples of English literary texts as a requirement for their learning courses and this is their first academic meeting with English literature subjects.

Poetry were chosen to be read by participants should be covered as a side program along with other reading material assigned by the lecturer. Three short poems entitled "Nothing Gold Can Stay" by Robert Frost, "The Sick Rose" by William Blake and "We Real Cool" by Gwendolyn Brooks are shared with the class program for six meetings.

\section{Data Collection Method(s) and Analysis}

This research used questionnaire as the main techniques in collecting the data. Descombe (1998) explained there are some advantages using survey techniques in collecting data:
1. Empirical data; it produces data based in the observation process.

2. Wide and inclusive coverage; it is able to implement on small and large scale.

3. Costs and time; it promotes low cost and effective time consumption in collecting the data.

\section{RESULT AND DISCUSSION}

From 25 students who took the literary understanding test, only 14 people responded. Of these 14 comments, as many as 7 (seven) students commented on the first poem, 6 (six) students gave responses to second poem, and only one person gave a comment on the third poem. Their responses are arranged in the following table.

Table 1: Students' Subjective Responses to three selected poems

\begin{tabular}{|c|c|c|c|}
\hline $\begin{array}{c}\text { Title of } \\
\text { the } \\
\text { poem }\end{array}$ & $\begin{array}{c}\text { Numbers } \\
\text { of } \\
\text { students } \\
\text { who give } \\
\text { responses }\end{array}$ & $\begin{array}{c}\text { Data } \\
\text { No. }\end{array}$ & $\begin{array}{l}\text { Students' } \\
\text { Subjective } \\
\text { Responses }\end{array}$ \\
\hline \multirow[t]{4}{*}{$\begin{array}{l}\text { Nothing } \\
\text { Gold } \\
\text { Can } \\
\text { Stay }\end{array}$} & \multirow[t]{4}{*}{7} & 1 & $\begin{array}{l}\text { "Nothing Gold } \\
\text { Can Stay" is a } \\
\text { poem that } \\
\text { discussed about } \\
\text { age. "Age" is } \\
\text { something "green" } \\
\text { but age can only } \\
\text { stay for an hour (a } \\
\text { while/not long) }\end{array}$ \\
\hline & & 2 & $\begin{array}{l}\text { This poem is about } \\
\text { nature. The poem } \\
\text { tells [us] to take } \\
\text { care the nature and } \\
\text { do not destroy it }\end{array}$ \\
\hline & & 3 & $\begin{array}{l}\text { In this poem tell(s) } \\
\text { about gold that } \\
\text { refers to "nature" } \\
\text { who can stay } \\
\text { because of human } \\
\text { that destroys the } \\
\text { nature without } \\
\text { using limitlessly }\end{array}$ \\
\hline & & 4 & $\begin{array}{l}\text { Nothing Gold Can } \\
\text { Stay (is) about all } \\
\text { the happening in } \\
\text { good in life (that) } \\
\text { cannot (be) } \\
\text { forever. All the } \\
\text { people have failed } \\
\text { in life, have good } \\
\text { life, have happy } \\
\text { life, and have sad }\end{array}$ \\
\hline
\end{tabular}




\begin{tabular}{|c|c|c|c|}
\hline & & & life \\
\hline & & 5 & $\begin{array}{l}\text { "Nothing Gold } \\
\text { Can Stay" tells } \\
\text { about how } \\
\text { important the age } \\
\text { is. Age is the most } \\
\text { priceless thing that } \\
\text { each person has, } \\
\text { we can't return } \\
\text { even for a second. } \\
\text { Even though it's } \\
\text { important thing, } \\
\text { many people don't } \\
\text { really care of how } \\
\text { they use their age. } \\
\text { This poem reminds } \\
\text { us to concern } \\
\text { about our age and } \\
\text { uses it only does } \\
\text { useful things in } \\
\text { life. Don't waste } \\
\text { even a second in } \\
\text { life. }\end{array}$ \\
\hline & & 6 & $\begin{array}{l}\text { Nothing Gold Can } \\
\text { Stay is a poem that } \\
\text { tells about } \\
\text { something that } \\
\text { can't stay forever. } \\
\text { This poem } \\
\text { symbolized parts. } \\
\text { This poem use(s) } \\
\text { personification and } \\
\text { metaphor } \\
\text { figurative language }\end{array}$ \\
\hline & & 7 & $\begin{array}{l}\text { Nothing Gold Can } \\
\text { Stay talks about } \\
\text { youth that doesn't } \\
\text { last long. It also } \\
\text { discusses about } \\
\text { when people are } \\
\text { still in their youth } \\
\text { they can try and } \\
\text { achieve many } \\
\text { things }\end{array}$ \\
\hline $\begin{array}{l}\text { The } \\
\text { Sick }\end{array}$ & 6 & 1 & $\begin{array}{l}\text { The poem talks } \\
\text { about illness }\end{array}$ \\
\hline Rose & & 2 & $\begin{array}{l}\text { The Sick Rose is } \\
\text { about the girl who } \\
\text { is sick. She lives in } \\
\text { an era where men } \\
\text { are in the upper } \\
\text { class. The author } \\
\text { feels sorrow about } \\
\text { the girl and writes } \\
\text { "The Sick Rose" }\end{array}$ \\
\hline & & 3 & $\begin{array}{l}\text { "The Sick Rose" } \\
\text { talks about despair, } \\
\text { sadness, and death. } \\
\text { "Rose" describe as } \\
\text { death }\end{array}$ \\
\hline
\end{tabular}

\begin{tabular}{|c|c|c|c|}
\hline & & 4 & $\begin{array}{l}\text { "The Sick Rose" } \\
\text { talks about a } \\
\text { woman's sickness } \\
\text { as a woman's } \\
\text { tragic experience. } \\
\text { "Rose" in this } \\
\text { poetry } \\
\text { perumpamaan the } \\
\text { woman }\end{array}$ \\
\hline & & 5 & $\begin{array}{l}\text { The poem of the } \\
\text { sick rose talk(s) } \\
\text { about } \\
\text { regretting the } \\
\text { teenager who fill } \\
\text { their life with } \\
\text { drugs and other } \\
\text { haram things }\end{array}$ \\
\hline & & 6 & $\begin{array}{l}\text { This poem is } \\
\text { talking about a girl } \\
\text { who got broken } \\
\text { heart because } \\
\text { cheating her } \\
\text { boyfriend and she } \\
\text { feel(s) her life is } \\
\text { destroy(ed) or } \\
\text { complicated } \\
\text { because of it }\end{array}$ \\
\hline $\begin{array}{l}\text { We } \\
\text { Real } \\
\text { Cool }\end{array}$ & 1 & 1 & $\begin{array}{l}\text { We Real Cool is } \\
\text { discuss(ing) about } \\
\text { the story of } \\
\text { friendship and how } \\
\text { it goes }\end{array}$ \\
\hline
\end{tabular}

Of the three poems given in the test, it seems that students are mostly interested in the poem entitled "Nothing Gold Can Stay". This poem was written by Robert Frost, one of the famous American poets. This poem has a theme about youth so it can be assumed that they are interested in giving responses to this poem because this poem is relevant to the age period they are enjoying right now.

The second poem that has the second most responses is responses to the poem entitled "The Sick Rose" written by William Blake. William Blake is well-known as one of the pre-romantic poets in England who wrote many poems related to the background in which he lived in. It can be assumed that this could be the reason that makes students were interested in exploring what is the meaning behind this poem.

While the poem that received the least comments from students was the poem entitled "We Real Cool" by Gwendolyn Brooks. She is a writer and an activist who observes social situations and conditions that form the ideas and background of her poetry. Perhaps this background aspect that students are not familiar with so it got the least comments. 


\section{DISCUSSION}

From the seven students' responses to Nothing Gold Can Stay, three students are able to demonstrate the process of re-symbolization in their understanding of the poem contents. They succeeded in attracting major keywords related to the poem such as "age" and /or "youth".

"Nothing Gold Can Stay" is a poem that discussed about age. "Age" is something "green" but age can only stay for an hour (a while/not long). (Response 1)

"Nothing Gold Can Stay" tells about how important age is. Age is the most priceless thing that each person has, it can't be returned even for a second. Even though it's an important thing, many people don't really care of how they use their age. This poem reminds us to concern about our age and uses it only for doing useful things in life. Don't waste even a second in life. (Response 5)

Nothing Gold Can Stay talks about youth that doesn't last long. It also discusses about when people are still in their youth they can try and achieve many things. (Response 7)

Several students also seemed to be able to show understanding but without formulating the process of re-symbolizing. Two comments gave descriptions but did not formulate the keywords that are expected to occur that indicate the understanding process.

Nothing Gold Can Stay is a poem that tells about something that can't stay forever. This poem symbolized parts. This poem use(s) personification and metaphor figurative language. (Response 6)

Nothing Gold Can Stay (is) about all the happening in good in life (that) cannot (be) forever. All the people have failed in life, have good life, have happy life, and have sad life. (Response 4)

Interestingly, some students associate this poem with the keyword "nature". Although these two students showed process of re-symbolization, but the keyword abstraction is actually not the main target. The primary theme is about age or youth, while nature can be included to sub theme.

This poem is about nature. The poem tells [about] take care the nature and do not destroy it. (Response 2)

In this poem tell(s) about gold that refers to "nature" who can stay because of human that destroys the nature without using limitlessly. (Response 3)

Meanwhile, six students' responses to The Sick Rose were more varied in taking keyword abstractions. It can be seen from four responses that re-symbolize the poem as "illness" or "sickness" even "death".

The poem talks about illness. (Response 1)

"The Sick Rose" talks about a woman's sickness because of a woman's tragic experience. "Rose" in this poetry is perumpamaan (of) the woman. (Response 4)

The Sick Rose is about the girl who is sick. She lives in an era where men is in the upper class. The author feels sorrow about the girl and writes "The Sick Rose". (Response 2)

Interestingly Response 2 also formulated secondary keywords "woman" or "a girl" and also "upper class". He/she even leveled up his/her responses by showing involvement of emotions of the author by using sentence "the author feels sorrow about the girl..." Another two responses formulated "teenager" and "broken-heart" as their re-symbolized process.

The poem of the sick rose talk(s) about the regretting the teenager who fill their life with drugs and other haram things. (Response 5)

This poem is talking about a girl who got broken heart because of her cheating boyfriend and she feel(s) her life is destroy(ed) or complicated because of it. (Response 6)

The last comment related to "We Real Cool" poetry shows that there is a keyword "friendship" as an indicator of the process of understanding poetry. Here is the sentence: "We Real Cool is discuss(ing) about the story of friendship and how it goes". Unfortunately, that is the only response to this poem.

\section{CONCLUSION}

Fourteen data in the form of responses shows the process of students' understanding of literary works, in this case to three short poems. As Bleich theory suggested, students are seen producing resymbolization of poetry as an indicator of their understanding process, although not all of them are able to do it accurately. This re-symbolization process is shown in the formulation of keywords 
which are the key to understanding the poems. It is unfortunate that these responses are not enriched by connection to feelings and emotions that show increasing stage of response.

Further researches are suggested to develop further of student responses in classrooms by using incorporating reader responses, especially for literary subjects. The class is a natural place for students to in studying literature. The focus on selfunderstanding is very motivating for most students, and Bleich subjective methods foster a kind of critical thinking that should prove to be beneficial for students throughout their lives because it shows that knowledge is created and is motivated by personal concerns.

\section{REFERENCES}

Bleich, David. (1975). Readings and Feelings: An Introduction to Subjective Criticism. Urbana IL: National Council of Teachers of English

Cobine, Gary R. (1996). Teaching Expressive Writing. Eric Digest. Available at http://ed.gov/databases/ERIC_Digests/ed39633 8.html/

Dascombe, BJ. (1998). Methods in Educational Research. London: University of Newcastle

Davis, Todd F and Kenneth Womack. (2001). A Humanistic Ethics in Reading: A Reader in Ethics, Culture, and Literary Theory. Charlottesville: University of Virginia Press

Eagleton, Terry. (1996). Literary Theory An Introduction. Second Edition. St. Catherine's College Oxford: Blackwell Publishing

Iser, Wolfgang. (1978). The Act of Reading. Baltimore: The Johns Hopkins University Press.

Iser, Wolfgang. (1989). Prospecting: From ReaderResponse to Literary Anthropology. Baltimore: The Johns Hopkins University Press.

Khatib, Sarvenaz. (2011). Applying ReaderResponse Approach in Teaching English Short Stories to EFL Students. Journal of Language Teaching and Research Vol.2 No.1, pp.151159
Langer, Judith A. (1991). Literary Understanding and Literature Instruction. Center on English Learning and Achievement. Available at https://eric.ed.gov/?id=ED333469

Mambrol, Nasrullah. (2016). Subjective Reader Response Theory in Today's Critical Theory: Easy-to-Use Guide. Loistyson Second Edition, Routledge

McQuillan, Martin. (2019). Literary Theory Media of Critical Practice. England: Bloomsbury Publishing Ltd

Nurcahyo, Pujo Sakti. Wordpress.com. Teori Transactional Reader Response. Retrieved November, 2019. Online available at https://pujosaktinurcahyo.wordpress.com/2011/ 01/27/teori-transactional-reader-response-2/

Purves, Alan C; Rogers, Theresa; and Soter, Anna O. (1990). How Porcupines Make Love II: Teaching A Response - Centered Curriculum. New York: Longman

Rosenblatt, Louise M. (1985). Transaction versus Interaction: A Terminological Rescue Operation. Research in the Teaching of English 19: 96-107.

Rosenblatt, Louise M. (1995, reprinted 1999). Literature as Exploration. The Modern Language Association of America.

Spiegel, Dixie Lee. (1998). Reader Response Approaches and Growth of Readers. Language Arts. Vol.76 No.1. September 1998

Subhan, Y. A. (2016). Gambaran Pemahaman Mahasiswa Terhadap Topik-topik Diskusi Sastra Anak dalam Pembelajaran di Kelas Sastra. In The 4th Literary Studies Conference (p. 213).

Thi My Van, Truong. (2009). The Relevance of Literary Analysis to Teaching Literature in EFL Classroom. English Teaching Forum No.3, 2009 